Translated Article ${ }^{\dagger}$

\title{
HARMONIZATION OF IRAOI ACCOUNTING OF FIXED ASSETS USING THE RUSSIAN ACCOUNTING STANDARDS AND IFRS
}

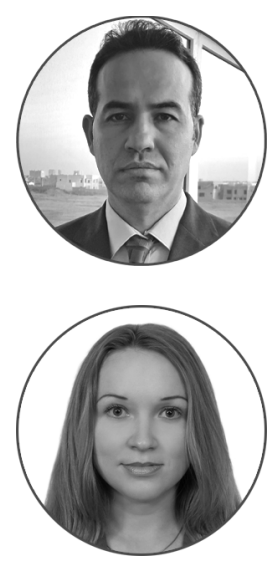

Article history:

Received 19 April 2017

Received in revised form 16 May 2017

Received in final form

2 September 2017

Accepted 30 October 2017

Translated 20 December 2017

Available online 27 March 2018

JEL classification: E23, M20, M41, N40

Keywords: fixed assets, reforming, accounting system regulation

\author{
Bilal A. ALSAEGH
}

University of Mosul, Mosul, Republic of Iraq

belalamjad@yahoo.com

\author{
Natal'ya V.ZYLEVA \\ Tyumen State University, Tyumen, Russian Federation \\ zyileva@mail.ru
}

\section{Corresponding author}


In Iraq, the procedure for fixed asset accounting is stipulated only in the Uniform Accounting System ${ }^{1}$, which is the law promulgating the principles of national formal accounting.

The Uniform Accounting System has been a vehicle for the centralized economic planning, economic and social development, control and compliance with principles of the economic system at the governmental level for many years, ensuring appropriate use of economic resources. Although Iraq is the place where both Stateowned and private companies operate, this national document still remains in effect, being the sole guidelines for the fixed asset accounting process since the Iraqi Accounting Standards simply do not exist.

It should be mentioned that the Uniform Accounting System encompasses such principles that prove to be irrelevant not only to ordinary users but also accountants. This fact avers that the Uniform Accounting System shall be updated.

PP\&E are defined as movable and immovable property of tangible and intangible nature, which contradicts the fact that nonphysical items are classified as intangible assets.

Disputable issues also arise from requirements to initial and subsequent valuation of PP\&E. For instance, the useful life of a PP\&E item does not influence the depreciation amount since depreciation is computed at the legally prescribed rate, rather than through a formula.

In our opinion, it is the right time for the Republic of Iraq to reform the PP\&E accounting practice since practical discrepancies of accounting principles and assessment of the financial result make financial reporting data of entities incomparable [1, p. 44].

As part of this research, we attempt to draft the Iraqi national standard on PP\&E accounting mainly by adopting the IFRS practices so as to harmonize the accounting rules. However, we also rely upon the positive outcome of Russia's accounting reform since Russia succeeded in harmonizing its accounting

\footnotetext{
${ }^{1}$ Uniform Accounting System (الموحد المحاسبي النظام). Federal Board of Supreme Audit of Iraq. URL: http://www.d-raqaba$\mathrm{m} . \mathrm{iq} /$ pages_ar/system muwahad_ar.aspx/ (Access date: March 16, 2017)
}

system inter alia by adopting the international accounting standards.

PP\&E valuation and accounting issues underlie proceedings by such Iraqi scholars as J.E. Al-Thabi, I.S. Mohammed [2], Sawsan Ahmad Saeed [3], H.H. Hussein, A.H.N. Bni lam [4], O.H.A. Alkarimsalum, H.H. Hashim [5], Ali Mal-Allah Abd-Allah [6]. However, they mostly focus on the way the valuation influences financial results, without analyzing accounting regulations.

Magdalena Lech and Małgorzata Kamieniecka analyzed PP\&E valuation during the transition to IFRS [7]. In the mean time, issues of PP\&E valuation methods and approaches were reviewed by Anna Majtánová, Lívia Sojková [8], Lisa Deane [9], economists of Municipal Development \& Lending Fund [10], Elizabeth S.R.M. Cole focusing on depreciation issues [11].

We should point out Steven M. Bragg [12], Daniela Cretu [13], who dealt with PP\&E accounting. Jörg Siebert and Dieter Schlagenhauf [14] reported on SAP software, which combines asset accounting concepts and determines the effect of requirements to PP\&E valuation under IFRS and US GAAP.

Scholars actively study issues that arise during the reform of the Russian accounting system from perspectives of the market economy and IFRS. The Russian researchers also concern issues of harmonizing PP\&E valuation and accounting.

Among recent researches, we shall point out a comparison of the PP\&E accounting terminology used in the Russian accounting standards (Russian PBU) and IFRS (E.S. Druzhilovskaya) [15], analysis of PP\&E valuation approaches based on international practices (V.S. Kazakova [16] and A.V. Novikova, E.V. Kudinova [17]), study into the effect of initial and subsequent measurement at fair value on the tax burden of the Russian entities (O.N. Kuznetsova) [18], comparison of the Russian accounting requirements with IFRS (T.V. Zav'yalova, E.V. Gudozhnikova, E.A. Vasil'eva [19], I.V. Rybalkina, N.N. Kosteva [20]).

We believe that the Republic of Iraq should rely upon other countries' expertise and practices of accounting reforms. Russia has come a long way in developing its accounting system and adopting IFRS. We consider 
Russia's experience as the most valuable for Iraq since accounting systems of both countries have similar traits, i.e. predominant governmental regulation of accounting processes and an impact of taxation laws on the way figures are recognized in accounting records [1, p. 38].

Exploring and summarizing requirements of IAS 16 Property, Plant and Equipment ${ }^{2}$, considering the imperfection of accounting processes in Iraq and the need for national accounting standards that would govern the way PP\&E are accounted for, and analyzing requirements of Russian PBU 6/01 Accounting for Fixed Assets $^{3}$ driving the convergence of the Russian companies with international practices, in this article we set out our own draft Iraqi Accounting Standard Fixed Assets, describe its possible sections and clarify the inadequacy of some clauses of Iraq's Uniform Accounting System, which is currently in effect.

Drawing upon principles of IAS 16 and Russian PBU 6/01, we outline the general design of the proposed Iraqi Accounting Standard Fixed Assets.

1. General provisions.

2. Recognition criteria and determination of a classification group.

3. Initial valuation of PP\&E.

4. Depreciation on PP\&E.

5. Expenditures for upgrade (retrofitting) and ongoing repair.

6. Impairment of PP\&E.

7. Valuation of PP\&E upon their recognition.

8. Disposal of PP\&E.

\footnotetext{
${ }^{2}$ International Accounting Standard 16 - Property, Plant and Equipment: Addendum № 8 to Order of the RF Ministry of Finance, On the Adoption of International Financial Reporting Standards and Clarifications to International Financial Reporting Standards in the Russian Federation, of December 28, 2015 № 217H (edited as of June 27, 2016). URL: http://www.consultant.ru/document/cons_doc_LAW_193590/ (In Russ.) (Access date: 16.03.2017)

${ }^{3}$ Russian Accounting Standard PBU 6/01 Accounting of Fixed Assets: Order of the RF Ministry of Finance of March 30, 2001 № 26H (edited as of May 16, 2016). URL:

http://www.consultant.ru/document/cons_doc_LAW_31472/ (In Russ.) (Access date: March 16, 2017).
}

\section{Accounting information in financial reporting.}

Any accounting standard shall start with the General Provisions section. The section shall pronounce the purpose of the standard, stating, for example, that this standard regulates the generation of information on the availability and movement of PP\&E in accounting records and its disclosure in financial reporting. Furthermore, there should be mentioned assets, which are out of the scope of the standard. For example, biological assets associated with agriculture.

The above section shall also enlist definitions and terms used in the standard, such as PP\&E (fixed assets), useful life, wear and tear, depreciation, impairment, historical cost, residual value, etc.

As per PP\&E accounting principles, that are currently effective in Iraq and set forth in the Uniform Accounting System, PP\&E are regarded as movable and immovable property of tangible and intangible nature, which has been acquired or constructed internally by the entity and situated in or outside Iraq. Such property is acquired to produce goods or deliver services, rather than to be sold.

In our opinion, this definition is incorrect since the intangible nature is characteristic of intangible assets, i.e. other items, which are accounted for in accordance with another Iraqi Accounting Standard. Furthermore, the definition fails to mention the intention of using the asset for a long time and administrative purposes of the entity.

Russian PBU 6/01 does not unfold the idea of fixed assets, but it sets forth four conditions for recognizing the asset as a PP\&E item (paragraph 4, PBU 6/01). As we see it, the definition is too large for the Iraqi standard, but the definition of fixed assets shall definitely specify that the item is intended for long-term use, i.e. the period of time exceeding 12 months or usual operating cycle, if it is more than 12 months.

IAS provide a more concise definition of fixed assets. As per IAS 16, PP\&E are tangible items that are held for use in the production or supply of goods or services, for rental to others, or for administrative purposes and expected to be used during more than one period.

As opposed to IAS, the Iraqi law and Russian standard envisage that the entity shall not plan any subsequent 
resale of a PP\&E item. We believe, this indication is not necessary since it mentions the need for long-term use of the asset for productive or administrative purposes.

Having reviewed definitions of PP\&E in the said regulations, we formulate the following one that would be advisable for the draft Iraqi Accounting Standard: Property, Plant \& Equipment shall mean tangible movable and immovable property the entity acquires or internally constructs with the intention of using it to produce goods or deliver services throughout the period exceeding 12 months.

The regulation should also feature some notions used to outline the PP\&E accounting procedure:

- useful life is the period of time, during which the asset will be held so that the entity could use it in line with the expected productivity or capacity and anticipated wear and tear that depends on operating conditions (the number of shifts), natural conditions and effect of an aggressive environment, repair system;

- depreciation on PP\&E is a regular allocation of the asset value throughout its entire useful life;

- impairment is a decrease in the value of an item due to wear and tear, obsolescence or changes in market prices;

- impairment loss is the difference between the carrying amount of the asset and its fair value less the cost of disposal;

- historical cost is the value, at which the asset is initially recognized in accounting records;

- carrying amount is the value, at which the asset is recognized in financial statements after accumulated depreciation and impairment losses;

- residual value of the asset is an estimated amount, which the entity would have received from the disposal of the asset at the current moment after deduction of expected disposal costs, if the useful life of the asset expired and the state of the asset were typical of its expired useful life;

- fair value is the amount that has been received upon the sale of the asset or paid to transfer the obligation as part of the orderly transaction of market actors as of the valuation date.
General provisions of the Iraqi Accounting Standards shall indicate a unit of PP\&E accounting. IAS 16 does not prescribe a unit of measurement, which is to be used to recognize PP\&E, and refers to a professional judgment concerning recognition criteria in each particular case. Iraqi accountants have yet to learn making a professional judgment. Thus, we consider it reasonable to indicate a measurement unit of PP\&E accounting in both the Russian Accounting Standards and Iraqi Accounting Standards and adopt an inventory item for this purpose. The inventory item of Property, Plant and Equipment is a physically separate item intended for autonomous functions, or a separate set of structurally connected items.

PP\&E are carried in accounting records at their historical cost (cost). The following section of the Iraqi Accounting Standards - Recognition Criteria and Determination of the Classification Group - shall specify the case, in which the cost of a PP\&E item shall be recognized as an asset. We guess IFRS provisions may be used in this respect, i.e. the cost of an item of Property, Plant and Equipment shall be recognized as an asset only if there is a probability that the entity will receive economic benefits from this item and the cost of the item can be accurately measured.

The idea of probability shall be incorporated to reflect the extent of uncertainty, to which the entity may lose or receive future economic benefits from a respective accounting item. Certainty can be ensured if principal risks and economic advantages are transferred to the factual holder of assets. In this respect, it is important to remember about such an accounting assumption as substance over form. Thus the ownership right is out of question at all. If economic benefits are not obvious, acquisition costs are posted to expenses of the current period.

In the list of conditions for recognizing an accounting item as PP\&E, Paragraph 4r, PBU 6/01 states that the entity intends to derive economic benefits (income) from PP\&E in the future, but overlooks the reliability of the item's cost measurement.

In fact, the reliability of the asset measurement seldom becomes a challenging point. However, the measurement may appear too biased in certain cases or have no cases to rely upon. For example, the case when a new type of assets is constructed 
through financial subsidies, being unparalleled in the market. It is problematic to assess future economic benefits from such an asset.

Many different PP\&E were grouped so to align their accounting treatment and recognition in financial reporting. The Uniform Accounting System of Iraq classifies Property, Plant and Equipment into the following main groups, such as land, buildings, facilities and transportation routes, machines and equipment, vehicles, tools and templates, furniture and office equipment, biological assets for water supply and production, deferred operating expenses (expenses for acquisition of services to be delivered within a period exceeding one year, including incorporation expenses). In this grouping, PP\&E are kept in accounting records and subsequently disclosed in financial statements by specified group.

IAS 16 also classifies Property, Plant and Equipment, (a) land plots; (b) land plots and buildings; (c) machines and equipment; (d) vessels; (e) aircraft; (f) motor vehicles; ( $g$ ) furniture and add-in engineering fittings; (h) office equipment. In IAS this classification is given as part of the accounting model at revalued amount. Assuming that a class of PP\&E is a group of fixed assets, which are similar in the nature and corporate use, if a certain PP\&E item is remeasured, the same shall be done with the other assets relating to the same class of fixed assets.

PBU 6/01 does not distinguish classification groups, with paragraph 5 only specifying that Property, Plant and Equipment include buildings, facilities, materials-working and power machines and equipment, measuring and controlling instruments and devices, computing equipment, vehicles, tools, production and household stock, draught animals, productive livestock and cattle, breeding stock, perennial plantings, local roads and other relevant items. On the one hand, they may be regarded as assets, which can be accounted as PP\&E, but, on the other hand, as groups of items stipulated in paragraph 18 of the Russian PBU, i.e. the entity shall use one of the methods for charging depreciation on a group of homogeneous items of PP\&E throughout the entire useful life of the items within the group.

Thus we believe that classification groups shall be stipulated in the draft Iraqi Accounting Standards not only to provide information on the groups in financial reporting, but also use them in the revalued amount-based accounting model. Reviewing the composition of the Iraqi PP\&E groups, we point out that the latter two groups (biological assets intended for water supply and production, and deferred operating expenses) can be excluded out of the list since their accounting specifics is set forth in Iraqi Accounting Standard 11 - Accounting in Agriculture ${ }^{4}$ and Iraqi Accounting Standard 2 - Intangible Assets ${ }^{5}$. After the two groups are deleted from the list, the remaining classification groups of PP\&E will be compliant with IAS.

Initial Measurement of Property, Plant and Equipment is another important section of the Iraqi Accounting Standards. The cost of PP\&E is formed depending on the way the entity obtains each particular fixed asset. Sale-purchase agreements are the most popular method to acquire PP\&E.

As for initial recognition of purchased PP\&E, the Uniform Accounting System of Iraq clarifies that, in this case, the value of the asset includes the purchase price, all acquisition expenses and cost of putting the item into operation for its intended use. The regulation refers to the situation when the land plot with an old building on it is purchased. In this case, the historical cost of the land includes expenses for the demolition of the old building, clearing and recovery of the land.

Considering that provisions of the Iraqi Accounting Standards on the historical cost of purchased PP\&E do not contradict IAS, though being less illustrative, we suggest outlining the draft Iraqi Accounting Standard on the basis of IAS 16.16-16.20 on the measurement of Property, Plant and Equipment to be recognized as assets. As per Russian PBU 6/01, when purchasing an item of Property, Plant and Equipment, its historical cost is made up of actual costs for acquisition, construction and production net of Value Added Tax and other recoverable taxes. Enlisted in the Russian

\footnotetext{
${ }^{4}$ Iraqi Standard of Accounting 11 - Accounting in Agriculture, of December 31, 1998 (المحاسبة في النشاط الزراعي). Federal Board of Supreme Audit of Iraq. URL: http://www.d-raqabam.iq/pdf/rule11.pdf (Access date: March 16, 2017).

${ }^{5}$ Iraqi Standard of Accounting 2 - Intangible Assets (as edited as of January 1, 2013) (الموجودات غير الملموسـة//2). Federal Board of Supreme Audit of Iraq. URL: http://www.d-raqaba-m.iq/pdf/rule2.pdf (Access date: March 16, 2017).
} 
PBU, actual costs included into the cost of an item do not contravene international standards.

As per the Uniform Accounting System of Iraq, exchanging PP\&E from different classification groups, the entity may make a capital loss (gain) as the difference between the carrying and market value of the transferred property. The regulation provides no explicit instruction but we can infer that their market value indicated in the exchange contract will be the historical cost of PP\&E acquired as a result of the exchange. This aspect is envisaged in paragraph 11 of Russian PBU 6/01, the historical cost of Property, Plant and Equipment acquired under non-pecuniary contracts is made up of the value of assets transferred or to be transferred by the entity, which is determined through the price the entity usually asks for similar assets in comparable circumstances.

Exchange transactions are the more thorough area of IAS. Measuring a PP\&E item acquired in exchange at fair value, the international standards also describe cases when it is not applicable to the cost of a PP\&E item: (a) the exchange transaction lacks commercial substance or (b) the fair value of neither the asset received nor the asset given up is reliably measurable. If the acquired item is not measured at fair value, its cost is measured at the carrying amount of the asset given up.

IAS regulates the way the entity determines whether the exchange transaction has commercial substance, considering the extent to which future cash flows are expected to change as a result of the transaction (IAS 16.25). To ascertain commercial substance of the exchange transaction, the value of a portion of the entity's operations, that is typical of the entity, shall reflect cash flows net of taxes. The result of the analysis may be obvious even if the entity does not make similar computations.

As per IAS, fair value is reliably measurable if limits of reasonable measurement of the asset value vary withing an insignificant deviation span for the asset, or it is possible to reliably assess the extent to which different estimates are probable within the limits and use it to measure the fair value. If the entity is able to reliably measure the fair value of the asset received or given up, the fair value of the asset given up is used to measure the cost of the asset received, unless the fair value of the asset received seems to be more evident. Neither Russian, nor international standards stipulate how the difference between the cost of the asset received and asset given up shall be accounted for, which is important for the Iraqi Accounting Standards.

Having analyzed all information, we conclude that the draft Iraqi Accounting Standards shall feature the following aspects in the paragraph Initial Recognition of Property, Plant and Equipment in Exchange: Initial recognition of PP\&E received in exchange depends on a loss or gain from the exchange as the difference between the carrying amount and market value of the property transferred, classification group, to which the transferred items pertain, and cash flows in the exchange transaction:

- if the exchange results in a loss, notwithstanding the classification group of the asset, the asset received shall be measured at fair value indicated in the exchange contract;

- if the exchange of PP\&E from different groups results in gain, the asset received shall be measured at fair value indicated in the exchange contract;

- if the exchange of PP\&E from the same group results in a gain without monetary proceeds, the asset received is measured at fair value indicated in the exchange contract;

- if the exchange of PP\&E from the same group results in gains and monetary proceeds, the asset received is measured at fair value indicated in the exchange contract net of the entire unrecognized gain, but including a percentage of gains derived from the exchange.

Gains (losses) from exchange of PP\&E is carried as investment profit (losses).

Lease as a type of finance lease helps to acquire PP\&E on deferred terms. However, Iraqi law and Russian standards do not refer to this method of acquiring PP\&E.

Whereas the Iraqi laws on accounting do not set any national standards governing lease accounting issues, these issues shall be stipulated in the fixed asset accounting standard. It will be easier for an Iraqi accountant to apply PP\&E accounting requirements, if all of them are consolidated in the same regulation. 
The accounting treatment of lease transactions can be clarified in IAS. These are the provisions which will underlie the draft Iraqi Accounting Standard. As per IAS 17 - Leases ${ }^{6}$, at the commencement of the lease term, lessees shall recognize finance leases as assets and liabilities in their statement of financial positions at amounts equal to the fair value of the leased property or, if lower, the present value of the minimum lease payments, each determined at the inception of the lease. The discount rate to be used in calculating the present value of the minimum lease payment is the interest rate implicit in the lease, if this is practicable to determine; if not, the lessee's incremental borrowing rate shall be used. Any initial direct costs of the lessee are added to the amount recognized as an asset. Subsequently, these assets are depreciated equally with other PP\&E of the entity.

The entity may acquire Property, Plant and Equipment as a pecuniary subsidy from the State. Neither the Iraqi accounting regulations, nor the Russian PBU on accounting of Property, Plant and Equipment provide recommendations on acquisition of PP\&E and lease accounting. In our opinion, the draft Iraqi Accounting Standard should be supplemented with the information on the historical cost of PP\&E acquired with the State subsidies as per paragraphs 24, 26, 27 of IAS 20 Accounting for Government Grants and Disclosure of Government Assistance ${ }^{7}$.

As per IAS 20, PP\&E acquired through government grants are initially recognized at fair value. Grants may be accounted for as deferred income or by deducting it in arriving at the carrying amount of the asset. If the grant is recognized as deferred income, it is posted to profit or loss on a systematic basis over the useful life of the asset. If the grant is accounted for by deducting it in calculating

\footnotetext{
${ }^{6}$ International Accounting Standard 17 - Leases: Addendum № 9 to Order of the RF Ministry of Finance to Order of the RF Ministry of Finance, On the Adoption of International Financial Reporting Standards and Clarifications to International Financial Reporting Standards in the Russian Federation, of December 28, 2015 № 217H (edited as of June 27, 2016).

URL: http://www.consultant.ru/document/cons_doc_LAW_193591/ (Access date: March 16, 2017).

${ }^{7}$ International Accounting Standard 20 - Accounting of Government Grants and Disclosure of Government Assistance: Addendum 12 to Order of the RF Ministry of Finance to Order of the RF Ministry of Finance, On the Adoption of International Financial Reporting Standards and Clarifications to International Financial Reporting Standards in the Russian Federation, of December 28, 2015 № 217H (edited as of June 27, 2016). URL: http://www.consultant.ru/document/cons_doc_LAW_193537/ (Access date: March 16, 2017).
}

the carrying amount of the asset, it is recognized in profit and loss over the life of a depreciable asset as a reduced depreciation charge.

Fair value (market value) of PP\&E acquired under a deed of gift (donation), i.e. free of charge, is regarded as the historical cost of such assets. This principle exists in both the Iraqi and Russian regulations and shall remain in the draft Iraqi Accounting Standard.

The Uniform Accounting System and Iraqi Accounting Standard 3 - Capitalization of Borrowing Costs set forth issues of initial recognition of PP\&E acquired under an investment loan ${ }^{8}$. As per the Uniform Accounting System, the historical cost of an asset shall include interests on loans, which directly relate to the acquisition, construction or production of the asset taking considerable time for its preparation for intended use. However, the Uniform Accounting System does not specify the moment when costs are no longer capitalized. Iraqi Accounting Standard 3 suggests ceasing to capitalize borrowings costs, when all work is almost completed to prepare the asset for intended use or sale. Iraqi Accounting Standard 3 also indicates that interests on the investment loan are treated as expenses reducing the current profit after borrowing costs are no longer capitalized. These requirements for accounting of borrowing costs are similar to those ones in paragraph 8 of PBU 15/08 Accounting of Borrowing Costs $^{9}$ and IAS 23.20 Borrowing Costs $^{10}$.

Hence the draft Iraqi Accounting Standard shall govern the initial recognition of PP\&E acquired under the investment loan agreement, indicating that interests on loans, which directly relate to the acquisition, construction or production of the asset taking

\footnotetext{
${ }^{8}$ Iraqi Accounting Standard 3 - Capitalization of Borrowing Costs (edited as of March 1, 2013) (رسملة كلف الاقتراض). Federal Board of Supreme Audit. URL: http://www.d-raqaba-m.iq/pdf/rule3.pdf (Access date: March 16, 2017).

${ }^{9}$ Russian Accounting Standard PBU 15/2008 - Accounting Regulation: Order of the RF Ministry of Finance of October 6, 2008 № 107H (edited as of April 27, 2012). URL: http://base.consultant.ru/cons/cgi/online.cgi? req=doc;base $=\mathrm{LAW} ; \mathrm{n}=131607$ (Access date: March 16, 2017)

${ }^{10}$ International Accounting Standards 23 - Borrowing Costs: Addendum № 14 to Order of the RF Ministry of Finance to Order of the RF Ministry of Finance, On the Adoption of International Financial Reporting Standards and Clarifications to International Financial Reporting Standards in the Russian Federation, of December 28, 2015 № 217H (edited as of June 27, 2016). URL: http://www.consultant.ru/document/cons doc_LAW_193569/ (Access date: March 16, 2017).
} 
considerable time to get ready for its intended use, are included into the historical cost of the asset and interests on the investment loan are treated as expenses reducing the current profit after borrowing costs are no longer capitalized. Afterward it is necessary to make a reference to Iraqi Accounting Standard 3 with more detailed information on the capitalization of borrowing costs.

The entity can construct an asset on its own, instead of purchasing it in the market. As per the Iraqi Accounting System, such assets are measured as an amount of actual costs. The Russian standard sets up identical requirements, without distinguishing the historical cost of PP\&E purchased and produced (constructed). IAS offers the most exhaustive recommendations for assessing the historical actual cost of PP\&E that the entity has constructed. According to IAS, the actual cost is assessed in line with all costs for designing, construction (assembling), mounting and delivery. Costs cease to be attributable to the value of PP\&E constructed, when a PP\&E item is installed at the intended place of operation and used for its immediate purpose.

Costs incurred to use or relocate the item are not included into its carrying amount. Costs for putting the item into full operation, losses at the initial stage of PP\&E operation are not capitalized. As per IAS, costs for dismantling of equipment from a land plot and land rehabilitation are not included into the value of the land plot, being subject to depreciation.

The value of PP\&E is reduced through depreciation. In this respect, Iraqi Accounting Standards shall have a section dedicated to depreciation of Property, Plant and Equipment.

Depreciation depends on the historical (recoverable) cost, useful life and depreciation methods. According to the Russian and international standards, the entity establishes the useful life of a PP\&E item and depreciation method for groups of assets when the item is entered into its accounting records.

Iraqi accounting laws do not provide for this possibility for entities. Thus the useful life of a PP\&E item has no impact on the amount of depreciation since depreciation is calculated at the legally prescribed depreciation rate, rather than a specific formula with the useful life ingrained in it. The law sets up the depreciation rate in line with the useful life of different PP\&E items. For example, building - 3\%, tow $15 \%$, motorbike - $25 \%$, tent - 50\%, furniture - $10 \%$, books - 100\%. Types of PP\&E and respective depreciation rates are enlisted on more than 20 pages of the legislative regulation. Therefore, the entity is not entitled to set up a useful life of a PP\&E item since law-makers have decided on it.

In our opinion, entities shall be empowered to have its own say on the term, during which they intend to use the asset so as to derive profit from it. We suggest adhering to factors stipulated in IAS 16.56. Russian PBU $6 / 01$, paragraph 20, also presents detailed guidelines for determining the useful life of PP\&E.

Although the Uniform Accounting System of Iraq prescribes four methods of depreciation (straight line, sum-of-the-years' digits (SYR), units of production and revaluation), most of them are virtually impracticable. For example, as the regulation rules, the revaluation method shall be applied only to calculate a depreciation on livestock and perennial bearer plantings. The regulation gives incorrect representations of the SYR method. The useful life is not used in such calculations at all. The law only states that the depreciation rate under the SYR method doubles. If this provision is interpreted closely to the original text, it will be difficult to trace the annually reducing depreciation unless we assume the depreciation rate shall be calculated through the carrying amount, rather than the historical cost. The units of production method is applied to air transport since depreciation is calculated in line with flight hours.

Thus, the straight line method appears to be the only practicable method as compared with those PP\&E depreciation methods permitted by the Iraqi law. However, we agree with IAS (paragraphs 43-62) that the applicable depreciation method shall reflect the expected way the entity plans to consume economic benefits from the asset. As opposed to IAS, in our opinion concerning PP\&E depreciation, it is necessary to regularly (every three to five years unless significant economic events take place) revise not only the depreciation method applicable to the asset, but also its useful life. If the expected consumption of future economic benefits embedded in the asset 
significantly changes, the useful life shall be modified accordingly ${ }^{11}$.

As for possible methods for charging a depreciation on PP\&E, the draft Iraqi Accounting Standards shall explicitly prescribe options to calculate depreciation amounts under each depreciation methods, drawing upon examples of IAS (paragraph 62) or Russian PBU (paragraph 19):

- straight-line depreciation method implies charging a default depreciation amount throughout the entire useful life of the underlying asset unless the residual value remains unchanged. The depreciation amount is calculated on the basis of the historical cost (recoverable amount) of the item and depreciation rate assessed in line with the respective useful life;

- sum-of-the years' digits method implies reducing the depreciation amount throughout the entire useful life of the underlying item. The depreciation amount is calculated on the basis of the historical cost (recoverable amount) of the item and the ratio of the number of years remaining before the expiry of the useful life and the sum of digits of the useful life years;

- units of production method implies charging the depreciation amount in line with the expected use or productivity. The depreciation amount is based on the physical indicator of output (work) in the reporting period and the ratio of the historical cost (recoverable amount) of the item and the expected output for the entire useful life.

Whereas the revaluation method of depreciation is permitted in Iraq only to calculate depreciation on the core herd animals and perennial bearer plantings, we believe that this method shall be integrated into Iraqi Accounting Standard 11 Accounting in Agriculture, rather than the national standard.

The Uniform Accounting System of Iraq outlines the only instance when the entity ceases to charge depreciation, i.e. it no longer uses the item due to military operations. This mention definitely stems from the political situation in the country. The regulation does not enumerate other cases when entities cease to

\footnotetext{
${ }^{11}$ Mohammad B.A., Zyleva N.V. [Reforming the accounting for oil wells depreciation in Iraq]. Mezhdunarodnyi bukhgalterskii uchet = International Accounting, 2016, no. 12, pp. 16-28. (In Russ.)
}

charge depreciation on PP\&E. However, we may guess that depreciation is no longer charged, if the item is disposed of in any manner. Provisions of IAS 16 help to illustrate the process, depreciation of an asset ceases at the earlier of the date that the asset is classified as held for sale and the date that the asset is derecognized.

We suggest the proposed draft should indicate accounting options for subsequent costs incurred for PP\&E maintenance, such as overhaul or ongoing repair (Costs for Retrofitting (Rehabilitation) and Ongoing Repair). Thus subsequent costs may be attributable to costs incurred during the period, or capitalized. Costs are included into the asset value if it is substantially retrofitted or rehabilitated, while similar costs for overhaul, that is the recovery of original properties and qualities, are attributable to expenses incurred during the period. So are costs for ongoing repair.

The asset value may happen to fall significantly during the useful life of PP\&E. For example, more rapid aging of an asset than expected, physical damage, etc. In this case, it is necessary to consider the impairment of a PP\&E item and disclose it in the following section of the draft Iraqi Accounting Standard, Depreciation of Property, Plant and Equipment.

IAS give a good insight into depreciation of assets. As per IAS 36 Impairment of Assets $^{12}$, at the end of each reporting period, an entity is required to assess whether there is any indication that an asset may be impaired. Impairment of assets may result from significant changes in the technological, economic conditions, obsolescence of an asset, physical damage to an asset and changes in the market environment, etc. If any of such indications is in place, the entity shall measure the recoverable amount of the asset. The recoverable amount is the higher of two values: fair value of the asset less costs of disposal and value in use. In our opinion, value in use is difficult to measure, especially in the Iraqi market. Thus only fair value can be used.

\footnotetext{
${ }^{12}$ International Accounting Standards 36 - Impairment of Assets: Addendum № 23 to Order of the RF Ministry of Finance to Order of the RF Ministry of Finance, On the Adoption of International Financial Reporting Standards and Clarifications to International Financial Reporting Standards in the Russian Federation, of December 28, 2015 № 217H (edited as of June 27, 2016). URL: http://www.consultant.ru/document/cons_doc_LAW_193674/ (Access date: March 16, 2017).
} 
The asset gets impaired, its carrying amount exceeds the fair value. As mentioned above, the international standard scrutinizes the impairment testing process and requirements to the way impairment amounts shall be accounted for. We suggest that the Iraqi Accounting Standard should refer to this international standard in terms of impairment accounting issues.

The draft Iraqi Accounting Standard shall have the section Measurement of PP\&E after Recognition that differentiates the valuation of an asset after recognition depending on an accounting model. As per IAS, the entity shall choose one of two PP\&E accounting models, i.e. accounting at the historical cost (actual costs) (IAS 16.30) or at revalued amount (IAS 16.31-42). Would-be investors need to know which model the entity adheres to in PP\&E accounting after their recognition since various models imply different ways for collecting financial reporting information.

The cost model conveys the historical cost principle, being preferable under IAS. As this model implies, financial statements shall present the cost of PP\&E less accumulated depreciation on PP\&E and accumulated impairment losses. As per the revaluation mode, the time, during which PP\&E are used, is one of the critical factors for PP\&E, increasing the probability of changes in the market value and divergence of the historical and fair value of an item. When such divergence is impossible to neglect, IAS 16 provides for an alternative approach to defining the subsequent measurement of PP\&E, i.e. the current market value, or recoverable amount less accumulated depreciation, unless the market value is known.

In our opinion, the revaluation model give a clearer view of the value of assets, especially in case of real estate, the market value of which increases in contrast to the carrying amount.

Although long-term acquisition is a PP\&E item, its value becomes subject to derecognition at some point of time. Thus if PP\&E are disposed or incapable of generating economic benefits (income) in the future, their value shall be derecognized. The accounting treatment of PP\&E ends up in derecognition of the actual (historical) cost and accumulated depreciation on the item. When derecognizing PP\&E, the entity may incur additional expenses and receive some earnings, which are to be posted to the Profit and Loss. These issues shall be reviewed in the section of the Iraqi Accounting Standards Disposal of Property, Plant and Equipment.

Like in all standards on accounting, the section Accounting Information in Financial Reporting shall become the final part. We believe that the Iraqi entities' financial statements shall disclose such information of PP\&E as (a) assets classified as held for sale; (b) existence and scope of titles for PP\&E, and PP\&E pledged to secure the fulfillment of obligations.

Following sections of financial statements shall present information on each group of PP\&E, such as the accounting model upon recognition, useful life; depreciation method; fair value of PP\&E, if it significantly differs from the carrying amount (the cost model); impairment losses included into (reinstated as part of) profit or loss (the cost model); growth or drop in the value resulting from revaluation (the revaluation model).

If PP\&E items are carried in accounting records and financial statements at the revalued amount, the following information shall be disclosed: (a) the revaluation date; (b) involvement of the independent appraiser; (c) the carrying amount, which would be recognized, if assets were not accounted through the cost model, by each class of revalued PP\&E; (d) growth in the revalued amount, indicating changes for the reporting period and restrictions to the distribution of the amount among shareholders.

If the draft Iraqi Accounting Standard on PP\&E accounting is composed as we describe above, it will be convenient to use because it will be compliant with the structure of IAS but its captions will be familiar to the Iraqi users. The proposed recommendations will help entities get a better understanding of the way they should account for PP\&E. It will also help national accounting principles and international standards converge. We hope this comparison and proposed draft for PP\&E accounting, in some way or another, will be embodied in Iraqi regulatory documents governing the PP\&E accounting procedure. 


\section{Table 1}

The fixed assets value to total assets value ratio (statistics for 2015)

\begin{tabular}{llll}
\hline Name of Company & Carrying amount of PP\&E, IQD & Total value of assets, IQD & Ratio, \% \\
\hline Baghdad for Packing Materials (Private) & $650,068,018$ & $1,008,209,537$ & 64 \\
\hline Baghdad Soft Drinks (Private) & $89,890,627,879$ & $226,907,311,687$ & 40 \\
\hline Al - Hilal Industries (Mixed) & $147,598,044$ & $3,326,096,895$ & 4 \\
\hline Iraqi Company for Carton Manufactures (Mixed) & $1,353,853,337$ & $1,739,554,014$ & 78 \\
\hline Iraqi Date Processing and Marketing (Mixed) & $4,112,973,379$ & $22,506,071,056$ & 18 \\
\hline Iraqi Engineering Works (Mixed) & $1,174,628,215$ & $1,582,025,199$ & 74 \\
\hline Iraqi for Tufted Carpets (Private) & $18,366,600$ & $2,790,375,822$ & 1 \\
\hline AL - Kindi of Veterinary Vaccines (Mixed) & $1,434,241,056$ & $6,287,325,944$ & 23 \\
\hline Al-Mansour Pharmaceuticals & $842,204,861$ & $8,006,206,671$ & 11 \\
\hline Modern Chemical Industries (Private) & $1,384,159,820$ & $9,914,364,840$ & 14 \\
\hline Modern Construction Materials Industry (Mixed) & $359,284,339$ & $1,639,283,379$ & 22 \\
\hline Ready Made Clothes \& General Trading (Mixed) & $33,310,233$ & $2,713,658,631$ & 1 \\
\hline The Light Industries (Private) & $640,197,367$ & $14,189,524,966$ & 5 \\
\hline
\end{tabular}

Source: Iraqi Stock Exchange data.

URL: http://www.isx-iq.net/isxportal/portal/companyGuideList.html

\section{References}

1. Mohammad B.A., Zyleva N.V. [Comparative analysis of the Iraqi and Russian accounting standards]. Vestnik Omskogo universiteta. Seriya Ekonomika = Bulletin of Omsk University. Series Economics, 2015, no. 2, pp. 37-47. URL: https://cyberleninka.ru/article/n/sravnitelnyy-analiz-irakskih-i-rossiyskih-standartov-buhgalterskogoucheta (In Russ.)

2. Al-Thabi J.E., Mohammed I.S. The Impact of the General Level of High Prices on the Valuation of Fixed Assets and Its Reflection on the Profitability of the Organization. The Journal of Administration and Economics, 2006, no. 49, pp. 114-132. URL: http://www.iasj.net/iasj?func=fulltext\&ald=66137 (In Arabic)

3. Sawsan Ahmad Saeed. The Possibility of the Optimal Selection the Method for the Evaluation of Fixed Assets in the Case of Privatization of the General Company of Soft Drinks in the Northern Region. Tanmiat Al-rafidain, 2009, no. 31(96), pp. 273-290. URL: http://www.iasj.net/iasj?func=fulltext\&ald=57527 (In Arabic)

4. Hussein H.H., Bni lam A.H.N. The Role of Fixed Assets in Achieving the Net Profit: An Applied Research on a Sample of Iraqi Private Banks. Al-Mamon College, 2016, no. 28, pp. 94-109.

URL: http://www.iasj.net/iasj?func=fulltext\&ald=118050 (In Arabic)

5. Alkarimsalum O.H.A., Hashim H.H. The Accounting Treatment for Fixed Assets in Alouhdataovernmah and Its Impact on the Financial Statements: Empirical Study at the University of Mustansiriya. The Journal of Administration and Economics, 2015, no. 104, pp. 204-221.

URL: http://www.iasj.net/iasj?func=fulltext\&ald=118846 (In Arabic)

6. Ali Mal-Allah Abd-Allah. Evaluating of Accounting Procedures of Fixed and Storing Assets in Iraq: Study of Sample of Governmental Units in Ninavah. Tanmiat Al-rafidain, 2009, no. 31(96), pp. 145-166. URL: http://www.iasj.net/iasj?func=fulltext\&ald=57511 (In Arabic)

7. Lech Magdalena, Kamieniecka Małgorzata. Valuation of Tangible Fixed Assets at the Moment of Transition to the IFRS/IAS (based on KGHM JSC.). Human Capital without Borders: Knowledge and Learning for Quality of Life, Management, Knowledge and Learning. International Conference, June 25-27, 2014. Portoroz, Slovenia. URL: http://www.toknowpress.net/ISBN/978-961-6914-09-3/papers/ML14-681.pdf 
8. Majtánová Anna, Sojková Lívia. Selected Modern Approaches to the Valuation of Fixed Assets for Insurance Purposes. Studia Ekonomiczne, 2014, vol. 183, part 2, pp. 98-109.

URL: http://cejsh.icm.edu.pl/cejsh/element/bwmeta1.element.desklight-5dc16791-f4e7-48e4-b147710bed9a8c75

9. Deane Lisa. Valuing Assets. Accountancy Plus, 2011, December, iss. 4, pp. 30-31.

URL: http://www.cpaireland.ie/docs/default-source/media-and-publications/accountancy-plus/inpractice/valuing-assets.pdf?sfvrsn=2

10. Fixed Assets Valuation Methodology. Municipal Development \& Lending Fund. Updated Version, December 2010. URL: http://www.mdlf.org.ps/pdfs/EFixedAssetsValuationMethodologyMarch2011.pdf

11. Cole Elizabeth S.R.M. Fixed Assets Depreciation Log. CreateSpace Independent Publishing Platform, 2017, January 26, $132 \mathrm{p}$.

12. Bragg S.M. Fixed Asset Accounting: Fourth Edition. USA, Accountingtools, Inc., 2017, January 8, 252 p.

13. Cretu D. Accounting and Tax Treatment of the Fixed Assets. LAP Lambert Academic Publishing, 2013, November 15, $124 \mathrm{p}$.

14. Siebert J., Schlagenhauf D. SAP Fixed Assets Accounting (FI-AA). CreateSpace Independent Publishing Platform, 2014, March 27, 206 p.

15. Druzhilovskaya E.S. [New terminological space in the field of Russian accounting of fixed assets and its correlation with the requirements of IFRS]. Bukhgalter i zakon = Accountant and Law, 2016, no. 1, pp. 2-14. URL: https://cyberleninka.ru/article/n/novoe-terminologicheskoe-prostranstvo-v-oblasti-rossiyskogo-uchetaosnovnyh-sredstv-i-ego-sootnoshenie-s-trebovaniyami-msfo (In Russ.)

16. Kazakova V. S. [Approaches to the valuation of fixed assets in the accounting on the basis of international practice]. Nauchnyi vzglyad v budushchee, 2016, vol. 8, no. 2, pp. 4-8. (In Russ.)

17. Novikova A.V., Kudinova E.V. [Problems of valuation of fixed assets in the transformation of financial statements into IFRS format]. Novaya nauka: Sovremennoe sostoyanie i puti razvitiya, 2016, no. 10-1, pp. 127-129. URL: http://www.i-ias.ru/blog/competition_page/problemi_ocenki_osn_sredstv.html (In Russ.)

18. Kuznetsova O.N. [The accounting of fixed assets on IFRS in Russia: collision of economic interests]. Sibirskaya finansovaya shkola = Siberian Financial School, 2016, no. 1(114), pp. 104-106.

URL: http://journal.safbd.ru/ru/issues/2016-no1-114-yanvar-fevral_article_104-106 (In Russ.)

19. Zav'yalova T.V., Gudozhnikova E.V., Vasil'eva E.A. [Comparative analysis of fixed assets accounting in domestic and international practice]. Fundamental'nye issledovaniya = Fundamental Research, 2015, no. 12, pp. $1215-1218$. URL: https://fundamental-research.ru/pdf/2015/12-6/39759.pdf (In Russ.)

20. Rybalkina I.V., Kosteva N.N. [Accounting for fixed assets under RAS and IFRS]. Innovatsionnaya nauka, 2015, vol. 1, no. 5(5), pp. 252-255. URL: https://cyberleninka.ru/article/n/uchet-osnovnyh-sredstv-po-rsbu-i-msfo (In Russ.)

\section{Conflict-of-interest notification}

We, the authors of this article, bindingly and explicitly declare of the partial and total lack of actual or potential conflict of interest with any other third party whatsoever, which may arise as a result of the publication of this article. This statement relates to the study, data collection and interpretation, writing and preparation of the article, and the decision to submit the manuscript for publication. 